\title{
When Freedom Isn't Free: The Costs of Judicial Independence in Bush v. Gore
}

\author{
PAMELA S. KARLAN ${ }^{*}$
}

In an earlier article, Two Concepts of Judicial Independence, ${ }^{1}$ I developed a taxonomy of meanings for the idea of "judicial independence" that draws on the distinction between negative and positive concepts of liberty. The constraints on judicial action range along a rough continuum-from those that raise concerns even under an exclusively negative conception, such as freedom from physical intimidation or freedom from direct pecuniary consequences, to those that pose problems only under an extremely robust positive conception, such as freedom from review by higher courts, freedom to ignore precedents, and freedom to pursue a conception of the good or the just that contradicts positive law.

In this article, I apply that framework to the litigation surrounding the presidential election of 2000. I show how that litigation implicated a number of aspects of judicial independence. With respect to the justices of the Florida Supreme Court, I consider questions such as the effect of their status as popularly elected officials, their position within the judicial hierarchy, and the peculiar relationship among the branches of government in presidential election cases. With respect to the members of the United States Supreme Court, I discuss the implications for judicial independence of potential personal stakes in the outcome of the litigation; individual justices' desire to influence the future composition of the Court; and the Court's freedom from direct political control. Finally, I explore ways in which the United States Supreme Court's decision in Bush v. Gore reflects two particularly aggressive and troubling assertions of judicial independence. First, the Court saw itself as free to determine the meaning of Florida law for itself, without regard to the views of the Florida Supreme Court. Second, the per curiam opinion ignored pervasive constraints on individual judges' ability to pursue their own ends that precedent and stare decisis normally impose.

\section{INTRODUCTION}

The Duchess of Windsor famously observed that you can never be too rich or too thin. Most discussions of judicial independence take a similar stance-there is no such thing as too much. In an earlier article, Two Concepts of Judicial

* Kenneth and Harle Montgomery Professor of Public Interest Law, Stanford Law School. I presented a version of this article at the Ohio State Law Journal's 2002 Symposium, "Perspectives on Judicial Independence." Viola Canales made several helpful comments on an earlier draft.

${ }^{1}$ Pamela S. Karlan, Two Concepts of Judicial Independence, 72 S. CAL. L. REV. 535 (1999). 
Independence, I suggested that this unanimity reflects a failure to define what judicial independence means. ${ }^{2}$ Drawing on Sir Isaiah Berlin's distinction between negative and positive concepts of liberty, ${ }^{3}$ I suggested that there are a range of possible meanings to the term "judicial independence" and that the ones that rest on a negative conception of autonomy are easier to justify than the ones that adopt a more positive approach. Indeed, strongly positive versions of judicial independence not only implicate the familiar countermajoritarian difficulty (when should courts override the judgments of the democratically elected branches?) but raise more basic questions about the relationship between judicial power and other people's freedom. When judges are completely free, the rest of us may not be.

In this article, I apply the framework developed in Two Concepts to the litigation surrounding the presidential election of $2000.4^{4}$ I describe the various aspects of judicial independence that came into play and show that arguments about judicial independence can be deployed by critics on every side, precisely because the idea of judicial independence is such a slippery one. And I suggest that the closing act of the drama-the United States Supreme Court's per curiam decision in Bush $v$. Gore ${ }^{5}$ - constituted an aggressively independent judicial act. The Supreme Court's decision thus illustrates some of the dangers that come from elevating judicial independence over the constellation of other values courts also serve.

\section{FROM "FROM" TO "TO": THE RANGE OF UNDERSTANDINGS OF JUDICIAL AUTONOMY}

Put in its simplest terms, a negative conception of judicial independence consists in "warding off interference"6 from external influences. Under a positive conception, by contrast, judges are engaged in "conceiving goals and policies of [their] own and realizing them."7 A shorthand way of explaining the distinction uses the verbal formulations "freedom from" and "freedom to." In a negative conception, the actor is free from some outside control on her ability to act. In a

\footnotetext{
2 See id.

${ }^{3}$ That distinction is presented in ISAIAH BERLIN, Two Concepts of Liberty, in FouR ESSAYS ON LIBERTY 118 (1969).

${ }^{4}$ For extensive accounts of how that litigation unfolded, see, for example, SAMUEL Issacharoff, Pamela S. Karlan, \& Richard H. PILDES, WHEN Elections Go BaD: The LAW OF DEMOCRACY AND THE PRESIDENTIAL ELECTION OF 2000, at 28 (rev. ed. 2001); Larry D. Kramer, The Supreme Court in Politics, in THE UNFINISHED ELECTION OF 2000, at 105 (Jack N. Rakove ed., 2001).

5531 U.S. 98 (2000).

${ }^{6}$ BERLIN, supra note 3, at 127 .

${ }^{7}$ Id. at 131.
} 
positive conception, the actor is free to realize a particular internally generated goal.

In Two Concepts of Judicial Independence, I described a series of potential constraints on a judge's autonomy. I arranged them along a rough continuumfrom those that raise concerns even under an exclusively negative conception of judicial independence to those that pose problems only under an extremely robust positive conception:

\author{
Physical Compulsion \\ Pecuniary Consequences \\ Personal Ambition \\ The Political Branches \\ The Judge's Own Background \\ Higher Courts \\ The Law $^{8}$
}

The polar ends of the spectrum can be illustrated by examples of what did not happen in the presidential election litigation. If, for example, a mob had gathered around the Florida Supreme Court and had threatened to burn the building down unless the justices ruled in favor of George W. Bush, that would have implicated the most negative form of judicial independence: judges must be, and feel themselves to be, free from physical coercion. ${ }^{9}$ At the other end of the spectrum: suppose the United States Supreme Court had announced that the election should be determined by the popular vote total because the Electoral College reflects an anachronistic vision of American democracy, ${ }^{10}$ and therefore declared $\mathrm{Al}$ Gore the winner. Such a decision to depart from the constitutional framework-the "supreme Law of the Land" 1 -could be justified only by a ludicrously robust version of judicial autonomy in which judges are free to remake the American political system without any constitutional warrant. ${ }^{12}$ Leaving aside these

${ }^{8}$ While I am quite confident that freedom from physical compulsion and freedom to create the law oneself mark the ends of the spectrum, the relative positions of some of the intermediate constraints might shift depending on the context. As this essay suggests, in the context of the presidential election litigation, an argument in favor of judicial independence from the political branches may involve a more aggressive assertion of autonomy than an argument of judicial independence from a judge's own background would.

${ }^{9}$ Cf. JefFrey TOOBIN, TOO Close to CALl: The THIRTY-SiX-Day Battle to DeCide THE 2000 ELECTION 156 (2001) (describing how Republican partisans formed "the Brooks Brothers mob" and stormed a Dade County office building, chased officials down the hall, and pressed county officials to stop recounting ballots).

${ }^{10}$ See Jack N. Rakove, The E-College in the E-Age, in THE UNFINISHED ELECTION OF 2000 , supra note 4 , at 201.

${ }^{11}$ U.S. CONST. art. VI, $\S 1, \mathrm{cl} .2$.

12 In fact, much of the criticism of prior judicial forays into the political thicket has rested on the contention that the majority has simply enacted its own political preferences. See, e.g., 
extremes, it turns out that the litigation surrounding the presidential election raises interesting versions of all of the intermediate constraints.

\section{A. Freedom From Direct Personal Stakes and Pecuniary Consequences}

A cornerstone of due process is the understanding that judges must be free from having a personal interest in the outcome of the cases they hear. ${ }^{13}$ If Justices Scalia or Kennedy thought that their prospects for becoming chief justice depended on Bush's becoming president, ${ }^{14}$ and this possibility affected their view of the merits of Bush v. Gore, then personal arnbition would have compromised judicial independence. If Chief Justice Rehnquist or Justice Scalia were influenced in their view of the case by their hope that their children might be nominated to high government posts in a Republican administration, ${ }^{15}$ this raises the same problem. Similarly, if Justice O'Connor "wanted to retire to Arizona, and a Gore win meant [she would] have to wait another four years ... [because she] did not want a Democrat to name her successor," 16 then we might properly be concerned that her position in Bush $v$. Gore raises the appearance that she had an illegitimate stake in the outcome. ${ }^{17}$ My own view is that all of the jurists involved in the presidential election litigation were committed to keeping their personal interests in the outcome of the election from influencing their resolution of the legal issues before them. As I shall suggest later, however, even if narrow self-interest did not distort their analysis, the lens through which judges

Holder v. Hall, 512 U.S. 874, 896-903 (1994) (Thomas, J., concurring in the judgment); Baker v. Carr, 369 U.S. 186, 269-70, 298-302 (1962) (Frankfurter, J., dissenting).

${ }^{13}$ See Ward v. Village of Monroeville, 409 U.S. 57, 62 (1972).

${ }^{14}$ Cf. Tony Mauro, Fractious Episode Likely to Affect Justices' Future on the Bench, TEX. LAW., Dec. 18, 2000, at 18, available at LEXIS, Allnews File (remarking that "[J]usticesScalia and Thomas, most notably - who might have had ambitions to be elevated to [C] [Justice by a President Bush may have to defer those dreams" because "Democrats would likely view any elevation of a sitting justice as an unseemly payback for ruling in Bush's favor"). The accusation that this possibility motivated the justices - that the Supreme Court's decision was corrupt in the old-fashioned sense of the word-has been raised by observers such as Alan Dershowitz. See Alan M. DershowItz, SuPREME INJUSTICE: How THE High COURT HUACKED ELECTION 2000, at 162-63 (2001) (suggesting that Justice Kennedy might have been influenced by his desire to become the next chief justice).

15 Janet Rehnquist was nominated and confirmed for the position of Inspector General of the Department of Health and Human Services. Eugene Scalia, after much controversy, received a recess appointment as Solicitor of the Department of Labor.

${ }^{16}$ According to a story in Newsweek, Justice O'Connor's husband gave this explanation to other partygoers at an election night party after the Justice expressed distress when CBS News announced Gore had won Florida. Evan Thomas \& Michael Isikoff, The Truth Behind the Pillars, NEWSWEEK, Dec. 25, 2000, at 46, 46.

17 I discuss this question in more detail infra text accompanying notes 48-52. 
considered the legal claims might have been colored by knowledge about outcomes.

\section{B. Freedom From Electoral Retribution and a}

\section{Judge's Personal Background}

The constraints I described in the previous section are unambiguously illegitimate: Everyone would agree that they should not affect a judge's decision. But there are other forms of personal ambition that begin to raise the question whether judicial independence should be unlimited. Most judges want to keep their current jobs. Given the widespread use of popular elections to choose state court judges, many discussions of judicial independence focus on the threat to judicial independence posed by the desire to stay in office. Because the electorate may retaliate against judges who render unpopular decisions, judges may be tempted to temper justice with self-preservation.

How we think about this aspect of judicial independence may depend on how we frame the question. If we ask, "Should judges be free from the fear they will be tossed out of office for making a correct but unpopular decision?," the answer is sure to be "Yes." Posed this way, the question pushes us back toward the entirely negative conception of judicial independence that underlies freedom from physical coercion (conveyed by the metaphorical "tossed out of office") or direct personal benefit (since electoral defeat will deprive them of the emoluments of office). Putting the question this way presupposes the existence of cases where there is a clear legal rule, but either the rule or one of the litigants is unpopular. The very nature of the judicial act requires that judges not bend the rule because of popular views about the rule or its application to particular litigants.

But there will be many situations in which either the rule is not clear or the case calls for judges to exercise equitable discretion. These cases may lead us to ask the question differently: "Must the voter who believes in judicial independence disregard a judge's views in deciding how to vote in a retention election?" It is far more difficult to answer this question with a categorical "Yes." Consider a voter who disagrees with a judge's approach to key questions of state constitutional law concerning, for example, the right to privacy. ${ }^{18}$ Should that

${ }^{18}$ Many state constitutions contain such provisions. See, e.g., FLA. CONST. art. I, $\$ 23$ ("Every natural person has the right to be let alone and free from governmental intrusion into the person's private life except as otherwise provided herein."). The Florida Supreme Court has repeatedly held that the Florida Constitution provides broader privacy rights than the United States Constitution. See, e.g., Renee B. v. Fla. Agency for Health Care Admin., 790 So. 2d 1036, 1039 (Fla. 2001) (reiterating this position); In re T.W., 551 So. 2d 1186, 1190-92 (Fla. 1989) (using the Florida constitutional provision to strike down restrictions on minors' access to abortions that might well have passed muster under federal constitutional principles). In a similar vein, the Georgia Supreme Court relied on a more capacious reading of the Georgia Constitution's due process clause to strike down precisely the sodomy statute that the United 
voter nonetheless feel constrained from voting against her because the judge is honest and not demonstrably incompetent? Or consider the voter who takes a fundamentally different view of what equality means. Should he be required to ignore evidence that a candidate for judicial office takes a narrower (or a broader) view? ${ }^{19}$

With these considerations in mind, let us turn to the situation of the Florida Supreme Court in the Bush v. Gore litigation. Unlike the United States Supreme Court, the Florida Supreme Court is not insulated from the electorate: its members must stand for retention every six years. ${ }^{20}$ Did this difference render the Florida Supreme Court less independent as a descriptive matter? And should we care? In general, we might assume that the higher the profile of a case, the greater the importance of political insulation. But in the distinctive context of postelection litigation over electoral results, there may be a countervailing argument: the political accountability of the Florida Supreme Court may have made it a more appropriate forum for deciding who won Florida's electoral votes.

States Supreme Court upheld against a due process challenge in Bowers v. Hardwick, 478 U.S. 186 (1986). See Powell v. State, 510 S.E.2d 18, 22 n.3 (Ga. 1998).

19 To give a concrete example, consider In re Petition for Removal of a Chief Judge, 592 So. 2d 671 (Fla. 1992) (per curiam). In that case, the Florida Supreme Court removed Judge John Santora from his position as chief judge of one of the state's judicial circuits because of statements he had given in a newspaper interview. The Florida Supreme Court did not address his fitness to continue as a judge. Id. at $671 \mathrm{n} .1$. In the interview, Judge Santora made the following comments (among many others):

I would not date a black girl. I would not take one hone, my mother would kill me .... I would not want my children to marry a black or an Asian or a Chinese or a Puerto Rican. I would not want them to. And they know that. I have friends who are black, we all do. You have them in your workplace; I've got 'em in my workplace. The best judicial assistant in this building, one of the best, is a black girl. One of the best, without a doubt. But that's unusual. One of the best judges is black. One of the worst is black. I think that there is a difference between a lot of them that they can't overcome. And it's not all of it their fault. It's the fault of their mothers and their daddies and their ancestors. And our fault. We have been too good to them. We, the United States Congress. Because they make more money by staying home on welfare than they do working. And you can't blame 'em. Why give up $\$ 1,500$ a month when you can't make but $\$ 800$ working.

Id. at 673 .

Certainly, judges enjoy First Amendment rights. And Judge Santora insisted in the interview that he set aside his personal views about race when he stepped onto the bench. But does a commitment to judicial independence really mean that a Florida voter should not consider Judge Santora's views (or, put more tendentiously, retaliate against him for exercising his constitutional rights to free speech and freedom of association) in deciding whether to vote for him?

${ }^{20}$ This requirement may have been largely formal: Apparently no justice has ever been defeated in a retention election. See Kevin P. Connolly, GOP Wants to Tighten Grip on Supreme Court: Republicans Cowin and Brummer Will Try to Give Future Governors the Power to Remove Justices, ORLANDO SENTINEL, Jan. 21, 2002, at B3. 
The question of electoral accountability is distinct from the issue of partisanship (which might have been categorized by my earlier taxonomy as reflecting a judge's personal background). I would expect unanimous support for the proposition that judges should be free from partisan bias, and not decide cases based on the political identity of the litigants. The tone of the debate over the Florida and United States Supreme Courts' decisions illustrates this point. Each court was criticized for being partisan, that is, for picking interpretations that favored the electoral prospects of the candidate whose party affiliation the majority shared. But in a wide-open debate in which virtually every conceivable position (and then some) was taken by somebody, no one defended either court by conceding, and then justifying or excusing, political motivations. That is, each court's supporters staunchly denied charges of partisanship.

Of course, the justices (on both courts) may have been deluding themselves. As I shall suggest in a moment, the law in this case was hardly clear-cut. There were a variety of lenses through which to view the various subsidiary legal questions. Which one a judge selected might well be the unconscious product of knowledge that one approach would result in victory for the candidate she favored, while the alternative would result in his defeat. This is one powerful reason why, to the extent it is possible, cases involving the political process should be litigated before elections occur, while judges are still behind a veil of ignorance. When elections are challenged after the fact, every procedural and substantive decision can be outcome determinative. When the partisan effects of all potential courses of action are known both to the judges and to the public, there is a risk that every decision will be publicly perceived as driven by its likely consequences. Thus, the adjudication of claims that can alter the outcomes of high-profile elections threatens significant damage to the public's confidence in judicial independence, whatever the reality. ${ }^{21}$

In any event, I have not seen any argument that persuades me that the Democrats on the Florida Supreme Court were more pervasively yellow dog than the Republicans on the United States Supreme Court were rock-ribbed. To begin with, more members of the United States Supreme Court than of the Florida Supreme Court stood to benefit directly from a decision about who should be the next president. In the end, a majority of the justices on both courts cast votes consistent with the immediate interests of the party that had appointed them, but two Democrats on the Florida Supreme Court and two Republicans on the U.S. Supreme Court voted against the immediate interests of their party's standard bearer.

Returming, then, to the question whether the status of the Florida Supreme Court as an elected body posed a threat to its independence in the presidential election litigation, I am fairly confident that the answer is "No." It is hard to identify anything in the Florida Supreme Court's rulings that suggests that its

${ }^{21}$ ISSACHAROFF, KARLAN, \& PILDES, supra note 4, at 3. 
members were influenced by their prospects for retention. There was no reason to be. While the Court's decisions spawned creation of groups dedicated to defeating Justice Harry Lee Anstead and Chief Justice Charles Wells in the 2002 election, that effort quickly died down. ${ }^{22}$ And its ultimate failure was entirely foreseeable. ${ }^{23}$

Still, it is worth asking about the normative significance of the Florida Supreme Court's status as an elected body. For a variety of reasons, I think this made the Florida Supreme Court a better, rather than a worse forum, for resolving the case.

To understand why, it is important to acknowledge that, despite the vehemence of many partisans, the issues raised in the litigation were not clearcut. ${ }^{24}$ To begin with, the three federal constitutional provisions implicated by the case-Article II, section 1, the Twelfth Amendment, and the Fourteenth Amendment's Due Process and Equal Protection Clauses-had never been interpreted in an even remotely analogous case. ${ }^{25}$ The Electoral Count Act of 1887,26 the federal statute governing the receipt and determination of electoral votes, had never before been construed, and raised constitutional questions all its own. ${ }^{27}$ Moreover, the Florida Election Code was a model of ambiguity: What

22 See Dan Christensen, Merit Retention; PAC's Attack Fizzles: Committee's Effort to Oust Two Florida Justices Leaves Mysterious Money Trail, BROWARD Dally BUS. REV., Feb. 25,2002 , at A9.

${ }^{23}$ Despite an effort to defeat then-Justice Rosemary Barkett's reelection bid to the Florida Supreme Court by death-penalty supporters and abortion foes, two groups who knew that their issues would repeatedly come before the court, Justice Barkett garnered over $60 \%$ of the vote in the closest retention election of recent times. See Claire Cooper, Fla. Court in the Crosshairs: Gore v. Bush Rancor Leads to Targeting of Justices (and Trial Lawyers), NAT'L L.J., Apr. 9, 2001 , at A1.

${ }^{24}$ For an extremely thoughtful discussion of the various issues, see Kramer, supra note 4.

25 I have suggested elsewhere that the concurrence's reliance on Article II, as well as the majority's assertion that Article II means that there is no affirmative federal right to vote in presidential elections, may be mistaken in light of the Fourteenth Amendment. See Pamela S. Karlan, Unduly Partial: The Supreme Court and the Fourteenth Amendment in Bush v. Gore, 29 FLA. ST. U. L. REV. 587 (2001); see also Peter M. Shane, Disappearing Democracy: How Bush v. Gore Undermined the Federal Right to Vote for Presidential Electors, 29 FLA. ST. U. L. REV. 535 (2001) (setting out a more extensive argument for why section 2 of the Fourteenth Amendment and the Due Process Clause require both recognizing a federal right to participate in presidential elections and a manual recount in Florida).

263 U.S.C. $\S \S 1-15(2000)$.

27 One example: Article II, section 1, clause 2 provides for a state to appoint its electors "in such Manner as the Legislature thereof may direct," a phrase that served as one of the linchpins for attacks on the Florida Supreme Court's decision, since critics argued that the Florida Supreme Court had usurped the legislature's prerogative in the way it interpreted the Florida Election Code and fashioned an innovative remedy. By contrast, 3 U.S.C. $\S 15$, which governs the procedure for handling disagreement between the two Houses of Congress over which slate to accept from a particular state, provides that "the votes of the electors whose 
counts as a legal vote?28 Can a manual recount be triggered by an "error in vote tabulation"--that is, an error in determining the candidates' vote totals-if there has been no "error in the vote tabulation system"- that is, no mechanical failure in the vote counting machinery? ${ }^{29}$ When one provision of Florida law provides that the Secretary of State "shall" ignore late-filed election returns in certifying election results, while a later-enacted provision states that the Secretary "may" ignore such returns, which section controls, and, if the latter one does, under what circumstances may the Secretary ignore late filings? ${ }^{30}$ Which aspects of the requirements for absentee ballot applications and absentee ballots are mandatory (thereby requiring the rejection of noncompliant ballots) and which are merely "directive," allowing such ballots to be counted?31 When is a ballot (like the notorious "butterfly ballot" used in Palm Beach County, which on virtually every account deprived $\mathrm{Al}$ Gore of at least 1700 votes) sufficiently defective that it requires some judicial remedy? ${ }^{32}$ When the Florida Election Code provides that a judge hearing an election contest "may fashion such orders as he or she deems necessary to ensure that each allegation in the complaint is investigated, examined, or checked, to prevent or correct any alleged.wrong, and to provide any relief appropriate under such circumstances," 33 what is an appropriate use of his or her equitable powers? When the ability of Florida to invoke the protections

appointment shall have been certified by the executive of the State, under the seal thereof, shall be counted." Thus, in a case where the legislature and the executive disagree, the constitutional provision and the statute are in tension with one another.

${ }^{28}$ Section $101.5614(5)$ of the Florida Statutes, which has since been repealed, provided in pertinent part, that " $[\mathrm{n}] \mathrm{o}$ vote shall be declared invalid or void if there is a clear indication on the ballot that the voter has made a definite choice as determined by the canvassing board." The Florida Supreme Court relied on this provision to hold that punchcard ballots on which the voter failed to completely detach the chad were nonetheless legal votes. See Gore v. Harris, 772 So. 2d 1243, 1256-57 (Fla. 2000). The instructions provided to voters expressly directed voters to check their ballot cards to be sure no chads were left hanging. See Bush v. Gore, 531 U.S. 98, 119 (2000) (Rehnquist, C.J., concurring). This led the three concurring justices to conclude that ballots that were not machine-readable because they were "not marked in the manner that these voting instructions explicitly and prominently specify" were not legal votes in the first place. See id.

${ }^{29}$ See Palm Beach County Canvassing Bd. v. Harris, 772 So. 2d 1220, 1228-29 (Fla. 2000) (discussing the issue).

30 See id. at 1233-34 (describing and resolving this conflict).

${ }^{31}$ See Jacobs v. Seminole County Canvassing Bd., 773 So. $2 d 519$ (Fla. 2000) (allowing noncompliant absentee ballots to be included in the vote total even though the local election officials had engaged in inappropriate behavior to assist Republican Party operatives).

32 See Fladell v. Palm Beach County Canvassing Bd., 772 So. 2d 1240, 1242 (per curiam) (Fla. 2000) (announcing that even if the plaintiffs' allegations were true, the butterfly ballot was not in "substantial noncompliance" with Florida law, and thus the plaintiffs' challenge of the Palm Beach County results had failed on a threshold issue).

${ }^{33}$ FLA. STAT. § 102.168(8) (2000) (repealed 2002). 
of the federal safe harbor statute ${ }^{34}$ conflicts with achieving a complete and accurate count, which should give way? To what extent does the Florida Election Code reflect the legislature's incorporation of a strong presumption, expressed in the Florida Constitution's Declaration of Rights, ${ }^{35}$ that all election laws should be construed in favor of "safeguard[ing] the right of each voter to express his or her will in the context of our representative democracy?"36

Stated another way, the election of 2000 presented questions whose answers depended on fundamental issues of constitutional philosophy. On the one hand, a judge might conceive of the right to vote as essentially a creature of state law in which citizens "must take the bitter with the sweet":37 if their ballots do not conform to explicit procedural requirements, they have not cast legal votes, and any process that threatens to include them in the official total represents judicial overreaching. If the as-yet uncounted ballots in Florida were not legal votes in the first place, ${ }^{38}$ then stopping the recount raises no problems at all. Or a judge might think that presidential elections are really about how electors appointed pursuant to state legislative directives select the national chief executive; in such a world, an individual citizen's right to participate in presidential elections might be considered contingent, ${ }^{39}$ while the state's interest in obtaining the safe-harbor benefits of the Electoral Count $\mathrm{Act}^{40}$ is fundamental. This judge might also find it easy to strike a balance in favor of stopping the recount even if that leaves ballots uncounted.

Conversely, a judge who believes that individual voters possess a fundamental liberty interest in participating in the presidential election and having their votes counted ${ }^{41}$ might adopt, as either a matter of statutory interpretation or as a constitutional imperative, a "clear intent of the voter" standard: all ballots

343 U.S.C. $\$ 5(2000)$ (providing that if a state completes its processes for determining its slate of electors at least six days before the electors cast their ballots, its determination shall be binding).

35 See FLA. CONST. art. I, §1.

36 Palm Beach County Canvassing Bd. v. Hàris, 772 So. 2d 1220, 1237 (Fla. 2000).

37 Amett v. Kennedy, 416 U.S. 134, 154 (1974) (plurality opinion). The Court has generally rejected the bitter with the sweet approach. See Cleveland Bd. of Educ. v. Loudermill, 470 U.S. 532, 540-41 (1985). Then-Justice Rehnquist, however, championed that approach. See Arnett, 416 U.S. at 154. Perhaps his concurrence in Bush v. Gore is intended to begin its rehabilitation.

${ }^{38}$ See Bush v. Gore, 531 U.S. 98, 119 (2000) (Rehnquist, C.J., joined by Scalia \& Thomas, JJ., concurring); see also Transcript of Oral Argument at 58, Bush v. Gore, 531 U.S. 98 (2000) (No. 00-949), available at http://election2000.stanford.edu/949trans.pdf (Justice O'Connor asks 'why isn't the standard [for deciding that a ballot contains a legal vote] the one that voters are instructed to follow, for goodness sakes? I mean, it couldn't be clearer. I mean, why don't we go to that standard?").

39 See Bush v. Gore, 531 U.S. at 104 (per curiam).

403 U.S.C. $\$ 5$ (2000).

${ }^{41}$ I explore this issue in Karlan, supra note 25, at 597-99. 
from which a voter's intent can reasonably be ascertained should be included in the final count, regardless of immaterial departures from state requirements. Starting from this perspective, a judge might strike the balance between additional manual recounts and a desire to wrap things up in time for the December 12 safeharbor deadline quite differently. Any process that leaves votes uncounted is justifiable only to the extent that it is necessary to achieve some other compelling state interest.

Given the difficulty of either determining who received the most legal votes in Florida or resolving underlying questions about the nature of voting rights under time constraints and with full awareness of the immediate partisan consequences, there seem to be good reasons to say that one of the more politically accountable organs of government should decide who should get Florida's electoral votes this time around. First, there is a plausible textual rationale for that approach. Article II, section 1 confers on each "State" (with a subsidiary delegation to "the Legislature thereof"42) the right to select electors. Both Article II, section 1 and the Twelfth Amendment expressly anticipate the counting of electoral votes before Congress. Thus, there is a strong basis for concluding that post-election contests over a state's electoral votes should be confided to Congress whenever possible. ${ }^{43}$

Second, there is something to be said for at least leaving Florida's electorate with some form of the last word over who deserved the state's electoral votes. Had the United States Supreme Court deferred entering the fray, then the Florida Legislature might have acted to appoint a slate of electors. Its decision would have been subject to review by the citizenry at the next election. Voters who thought $\mathrm{Al} \mathrm{Gore} \mathrm{had} \mathrm{won} \mathrm{the} \mathrm{election} \mathrm{or} \mathrm{who} \mathrm{thought} \mathrm{that} \mathrm{the} \mathrm{Legislature} \mathrm{had}$ improperly seized control over the selection of electors would have had a meaningful opportunity to express their views. Similarly, if the Florida Supreme Court had been left to answer the question, its members would have faced the electorate in their retention elections. The United States Supreme Court's complete insulation from Florida's voters made their decision the least democratic

42 The question whether the state's constitution nonetheless constrains the legislature's exercise of its powers was a source of some scholarly and judicial debate.

43 While an expansive version of this position might treat the selection of a state's electors as raising purely nonjusticiable political questions, I would not go that far, since the question whether a state's processes for selecting its electors deny an individual voter his rights under the Federal Constitution or federal statutes surely is justiciable. See Karlan, supra note 25, at 60102. But to the extent that the Court is being asked to vindicate something other than individual rights, the issue is probably better left to Congress. Elsewhere, I have argued that no individual voter's rights were in fact vindicated by the per curiam decision in Bush v. Gore. See Pamela S. Karlan, The Newest Equal Protection: Regressive Doctrine on a Changeable Court, in THE VOTE: BUSH, GORE, AND THE SUPREME COURT 77, 82-90 (Cass R. Sunstein \& Richard A. Epstein eds., 2001). 
way of ending the paradigmatically democratic process of holding popular elections.

\section{Freedom from the Political Branches}

The judiciary's position as one of three coordinate branches can circumscribe its freedom of action. This raises the question of the extent to which the judiciary ought to be free from legislative or executive control. The litigation surrounding the presidential election raises two unique aspects of this question.

The first concerns the constraints that Article II, section 1 imposes on the process of statutory interpretation. When it comes to statutory interpretation generally, most courts and commentators do not think courts should be too free from legislative control. The job of courts is to apply the statutory scheme enacted by the legislature. While there may be disagreements about canons of construction or the legitimacy of considering legislative history as well as text, courts generally do not see themselves as free agents.

An exception occurs when application of a statute implicates constitutional issues. Then state courts, like federal ones, generally see themselves as the ultimate arbiters. Thus, state courts can strike down state statutes as unconstitutional under both the federal and the state constitution (except to the extent that the state constitution itself confides a particular decision to another branch of state government). Similarly, they can construe state statutes to avoid constitutional issues or assume that the legislature would want them to interpret statutes in light of state constitutional values.

The litigation surrounding the presidential election raised an interesting question about whether state courts should be less free from legislative control when it comes to controversies over a state's electoral votes. In its initial decision requiring the Secretary of State to defer certifying the election until several counties could conduct manual recounts, the Florida Supreme Court relied on the Florida Constitution to provide a canon of construction. It began by noting the central role of the Declaration of Rights and described "[ $t]$ he right of suffrage" as "the preeminent right contained in the Declaration." 44 It therefore proclaimed that "[b]ecause election laws are intended to facilitate the right of suffrage, such laws must be liberally construed in favor of the citizens' right to vote ... . Technical statutory requirements must not be exalted over the substance of this right."45

The United States Supreme Court vacated the Florida Supreme Court's judgment. ${ }^{46}$ It sent the case back for clarification about the extent to which the Florida Supreme Court's construction of state law depended on the state constitution, suggesting, but never stating outright, that if the court had used the

\footnotetext{
${ }^{44}$ Palm Beach County Canvassing Bd. v. Harris, 772 So. $2 d$ 1220, 1236 (Fla. 2000).

45 Id. at 1237.

46 Bush v. Palm Beach County Canvassing Bd., 531 U.S. 70 (2000) (per curiam).
} 
state constitution to reach a result that the legislature had not intended, that would contravene Article II, section 1 of the federal constitution, which provided that electors were to be appointed "in such Manner as the Legislature... may direct." 47 Put concretely, if the state legislature had intended to impose either unreasonable or unnecessary restrictions on the right to vote in presidential elections ${ }^{48}$ or had decided to require hypertechnical compliance in order for a vote to be counted, the state courts would have been obligated to follow their directive, the Florida Constitution notwithstanding.

I do not have much to add to the already extensive literature about this question. My own sense is that it seems unlikely that a state legislature, whose members all take an oath to support the state's constitution, would have silently chosen to enact a statute that precluded the state judiciary from looking to the constitution to resolve unsettled interpretive questions. In other words, there was nothing in the text, structure, or legislative history of the Florida Election Code that suggested that the state legislature intended to constrain judicial autonomy in resolving presidential election contests beyond the constraints that governed all judicial review of elections.

The other interesting question about the relationship between judicial independence and political control concerns the United States Supreme Court. Over time, elections constitute a significant constraint on a central aspect of purely positive judicial autonomy - the ability of judges to realize a constitutional vision in the face of contrary public sentiment. If the public disagrees strongly enough with the Supreme Court's decisions, or cares deeply enough about a contested issue of constitutional law, it can elect a president or a Congress that shares its views and will nominate and confirm sympathetic justices. ${ }^{49}$ Put in terms of judicial independence, federal judges are not free to pick their successors. That task has been confided to the political branches.

If a justice's desire to be elevated to the chief justiceship or his desire to secure employment for his children is an illegitimate consideration, and it surely is, ${ }^{50}$ then a desire to control the future composition of the Court is an equally (if not more) impermissible factor in deciding a case like Bush v. Gore. But we should distinguish taking this factor into account in deciding a particular case from the more general concern justices may have in controlling future doctrinal development, or even in shaping the composition of future courts. Quite often,

47 See id. at 77.

48 Presumably, if those restrictions were so unreasonable or unnecessary that they violated the Due Process or Equal Protection Clauses of the Fourteenth Amendment, they would be invalid as a matter of federal law.

49 of course, this can be a somewhat imperfect process, given stealth candidates, changes of heart, and the emergence of unanticipated pivotal issues. (For example, none of the members of the Court at the time of Roe v. Wade, 410 U.S. 113 (1973), had been asked a single question about the contours of the constitutional right to privacy at his confirmation hearings.)

50 See supra text accompanying notes 14-17. 
justices will craft opinions in order to make it harder for future courts to overturn their rulings. As justices age, they may even discuss these issues more openly. Consider, for example, the last paragraph of Justice Blackmun's final opinion concerning abortion. After noting that the continued vitality of a woman's interest in reproductive autonomy depended on a "single vote," he stated:

I am 83 years old. I cannot remain on this Court forever, and when I do step down, the confirmation process for my successor well may focus on the issue before us today. That, I regret, may be exactly where the choice between the two worlds will be made. 51

And of course many justices time their retirements to give presidents of their own party the chance to fill their vacancies.

To my mind, a judge's decision to time her retirement or even to focus public attention on the issue of judicial nominations does not necessarily aggrandize judicial power impermissibly, because it leaves in place the overall structural checks provided by the appointments process. Thus, I am not particularly distressed by Justice O'Connor's initial upset at Al Gore's apparent victory-only a hopeless naif could think judges are uninterested in politics-or even her tentative decision to stick it out for another four years to avoid giving a Democratic president the right to nominate her successor. But I would be outraged if a justice's desire to keep the Democrats from filling a seat on the Court played any role in how he or she decided Bush v. Gore.

As Bruce Ackerman points out, the Supreme Court's decision in Bush v. Gore raises an appearance, at the very least, of this sort of aggressive assertion of judicial independence from the political branches and the political process:

[T]his time, the president has not been independently elected. He is in the White House as a result of an unprincipled judicial decision that brought the electoral contest to a premature end. If such a president is allowed to fill the Court, he will be acting as an agent of the narrow right-wing majority that secured his victory in the first place.

In our democracy, there is one basic check on a runaway Court: presidential elections. And a majority of the justices have conspired to eliminate this check. The Supreme Court cannot be permitted to arrange for its own succession. To allow this president to serve as the Court's agent is a fundamental violation of the separation of powers. It is one thing for unelected judges to exercise the sovereign power of judicial review; it's quite another for them to insulate themselves yet further from popular control. ${ }^{52}$

51 Planned Parenthood v. Casey, 505 U.S. 833, 94.3 (1992) (Blackmun, J., concurring in part, concurring in the judgment in part, and dissenting in part).

52 Bruce Ackerman, The Court Packs Itself, AM. PROSPECT, Feb. 12, 2001, at 48, available at LEXIS, Allnews File. 
Thus, Ackerman argued that the Senate should refuse to fill any vacancies until after the next presidential election. With that election still two years away, no justice has yet retired.

\section{BUSH V. GORE AS A MODEL OF JUDICIAL INDEPENDENCE}

Until now, I have been discussing judicial independence from external constraints. But the judicial process itself also constrains judges in a variety of ways. One of the most obvious constraints, which played some role in the presidential election litigation, is the hierarchical relationship among courts. The Florida Supreme Court, for example, was not free to ignore the decisions of the United States Supreme Court. ${ }^{53}$ Indeed, many observers wondered whether the Florida Supreme Court's decision to issue its opinion on the contest-phase recount before it responded to the United States Supreme Court's remand on the now superseded protest-phase question of the original certification may have contributed to the per curiam's apparent suspicion that it. was dealing with a runaway or disobedient state court.

I want to focus here, however, on two aspects of the United States Supreme Court's opinions in Bush v. Gore that suggest the decision reflects a particularly troubling assertion of judicial independence: freedom from "the law." By this, I do not mean to suggest that the Court's decision was lawless in the sense that there was no basis in the Constitution for its holding. As I have explained elsewhere, I think the Court's decision was wrong, particularly with respect to the remedy it ordered for the violation it found, but its legal reasoning was deeply flawed, not wholly absent.

The first example of the Court's assertion of freedom from the law is its decision to halt the recount altogether, rather than to remand the case to the Florida Supreme Court for it to decide whether to conduct a constitutionally adequate recount. In general, federal courts are not free to adopt their own construction of state law. A state supreme court's construction constrains them. Perhaps the per curiam's stance can be explained in part as a function of its sub rosa embrace of the Article II, section 1 theory that, as to the selection of electors, even a state court is not really free to construe state law but must be bound by the precise intent of the state legislature. Even so, the per curiam and the concurrence, which takes an even more disdainful stance as to the Florida Supreme Court's construction of state law, never squarely explain why justices of the U.S. Supreme Court are in a better position to divine the state legislative will-about issues on which the state legislatures that enacted the various provisions of the Florida Election Code never uttered a word-than the state court was. The per curiam's explanation of why it was stopping the recount altogether, rather than

53 I take up in a moment the question whether the United States Supreme Court was free to ignore the Florida Supreme Court's construction of its own law. 
remanding the case to permit the Florida Supreme Court to decide how to proceed, was remarkable for its disingenuousness. The per curiam explained its decision as dictated by legislative intent:

The Supreme Court of Florida has said that the legislature intended the State's electors to "participat[e] fully in the federal electoral process," as provided in 3 U.S.C. $\$ 5$. [Palm Beach County Canvassing Bd. v. Harris, 772 So. 2d 1220, $1239(2000)$.$] ... That statute, in turn, requires that any controversy or contest$ that is designed to lead to a conclusive selection of electors be completed by December 12. That date is upon us, and there is no recount procedure in place under the State Supreme Court's order that comports with minimal constitutional standards. Because it is evident that any recourt seeking to meet the December 12 date will be unconstitutional for the reasons we have discussed, we reverse the judgment of the Supreme Court of Florida ordering a recount to proceed. ${ }^{54}$

But the Florida Supreme Court actually said something quite different. It did not say that the state legislature intended that any contest be stopped on December 12 regardless of whether a required recount had been completed. Indeed, it was inconceivable that a state's failure to meet the safe-harbor deadline would deprive its electors of the right to participate fully. As long as the electors were appointed in time to cast their ballots on the designated day, December 18, there would be no problem with having some slate's vote counted. 55 Other sections of the Electoral Count Act suggest that the drop-dead date for casting a state's electoral votes might even have been as late as the fourth Wednesday in December (in 2000 , December 27$)^{56}$ or January 6 , when Congress actually counts the electoral votes. ${ }^{57}$ Neither on November 27 , when it extended the certification period, nor on December 8, when it ordered the statewide recount, did the Florida Supreme Court squarely address the state-law salience of the December 12 expiration of the safe-harbor provision. To paraphrase a famous observation of Judge Friendly,

54 Bush v. Gore, 531 U.S. 98, 110 (2000) (per curiam).

55 The safe-harbor provision seems superfluous. In most cases, there will be no dispute in the first place about the identity of a state's electors, and the provision will never come into play. In those cases where there is a dispute, it remains open to Congress to determine whether a state's electors were selected in compliance with 3 U.S.C. $\$ 5$, and it is entirely likely that proponents of a different slate will argue that the state's processes failed to comply with $\S 5$ because they marked a departure from previously enacted law.

56 See 3 U.S.C. $\$ \S 12,13$ (2000).

57 See id. $\S 15$. In Hawaii, for example, following the election of 1960, the acting governor originally certified the Republican slate of electors on November 28. A recount was begun on December 13. Both the Democratic and Republican slates met on December 19 (the appointed day that year) and each certified itself. On December 30, 1960, a court declared that the Democrats had won the election. Accordingly, the governor then certified the Democratic electors on January 4, 1961. Congress received the certification on January 6, and Hawaii's votes were counted. See William Josephson \& Beverly J. Ross, Repairing the Electoral College, 22 J. LEGIS. 145, 166 n.154 (1996). 
the United States Supreme Court was engaged in asking what the Florida courts would think about what the Florida legislature would think about a question about which neither of them had thought. 58

Perhaps the most pervasive internal constraint on an individual judge's ability to pursue her own ends stems from operation of precedent and stare decisis. The obligation that judges decide like cases alike is a key guarantor that judges will not decide cases based on the identity of the litigants (unless they can explain why the litigants are not similarly situated). The prospect that a particular rule of law may apply to future cases exercises some prospective constraining force as well, since it asks judges to consider the wisdom of applying more broadly the rule they are contemplating in a particular case.

In Bush v. Gore, however, the per curiam essentially announced its freedom not to apply the equal protection rule it had just announced to any other case:

The recount process, in its features here described, is inconsistent with the minimum procedures necessary to protect the fundamental right of each voter in the special instance of a statewide recount under the authority of a single state judicial officer. Our consideration is limited to the present circumstances, for the problem of equal protection in election processes generally presents many complexities. ${ }^{59}$

The most generous explanation for this extraordinary paragraph is that the majority knew that it was acting under tremendous time pressure, and was hesitant to announce a rule that could swiftly throw into doubt the constitutionality of a huge number of states' election systems. ${ }^{60}$ But precisely to the extent that the Supreme Court announces that it, and the lower courts, should feel free to decide future equal protection challenges without considering Bush $v$. Gore, it creates suspicion that its decision was result-oriented. That the Court felt free to announce this entirely new rule ${ }^{61}$ in a case with such tremendous stakes, and then immediately to repudiate the precedential value of its decision, marks a

58 See Nolan v. Transocean Air Lines, 276 F.2d 280, 281 (2d Cir. 1960). I leave aside the extraordinarily disdainful tone of the concurrence in discussing the state-law issues presented in Bush v. Gore because I do not think I can improve on Justice Ginsburg's response in her dissent. See Bush v. Gore, 531 U.S. at 135-41 (Ginsburg, J., dissenting).

59 Id. at 109.

60 Justice Stevens' dissent suggests the Court's awareness of this possibility. See id. at 124 n.2 (Stevens, J., dissenting) (noting that the vast majority of states use standards for counting ballots that were no more determinate than the Florida "clear intent of the voter" standard); id. at 126 (noting that the vast majority of states also delegate to local authorities control over the kind of voting machines used, thereby creating the same lack of uniformity that prevailed in Florida).

${ }^{61}$ I have explained elsewhere why the Court's conclusion was not dictated by prior equal protection precedents. See Pamela S. Karlan, Equal Protection: Bush v. Gore and the Making of a Precedent, in THE UNFINISHED ELECTION OF 2000, supra note 4, at 159, 187-94. 
staggering rejection of precedent's constraining force. As Justice Roberts caustically observed in another voting rights case decided nearly sixty years earlier, "the instant decision ... tends to bring adjudications of this tribunal into the same class as a restricted railroad ticket, good for this day and train only."62

\section{CONCLUSION}

The litigation surrounding the presidential election of 2000 illustrates a central point about judicial independence: we need to ask quite carefully what constraints judges ought to be free from, and what constraints judges ought to be bound by. In the end, judicial independence is not a single concept, but a constellation of different sorts of autonomy. Not every assertion of judicial autonomy is equally justifiable. Particularly when courts adopt aggressively independent stances, we must measure assertions of judicial autonomy against the competing claims of other actors within our system of democratic selfgovernment. In the election of 2000 , it turns out that the Supreme Court of the United States was in fact too free.

62 Smith v. Allwright, 321 U.S. 649, 669 (1944) (Roberts, J., dissenting). 